\title{
Relationship between International Trade and Economic Growth: A Cointegration Analysis for Zimbabwe
}

\author{
Gwaindepi Caleb \\ University of Limpopo, P Bag X1106, Sovenga, 0727, South Africa \\ Email: gwaindepi@gmail.com \\ Musara Mazanai \\ Monash South Africa (A Campus of Monash University, Australia), 144 Peter Road, Ruimsig, 1724 \\ Email: jilgram@yahoo.com \\ Dhoro Netsai L \\ Great Zimbabwe University, P O Box 1235, Masvingo, Zimbabwe \\ Email: nldhoro@gmail.com
}

Doi:10.5901/mjss.2014.v5n20p621

\section{Abstract}

The relationship between trade and economic growth has continued to dominate the debate in trade and development economics. Generally, countries which trade more have been seen to have a high growth path, some of which has been attributed to trade. However, it is very difficult to attribute much of the growth to trade and trade openness. The focus of this research paper is therefore to investigate if there exists a long run relationship between various trade and other macroeconomic variables for Zimbabwe for the period 1975 to 2005. The study employs the cointegration approach to establish the existence of a long run relationship between economic growth and trade variables. The results of the study indicate that trade and economic growth are cointegrated, but the relationship is strengthened by the stability of the macroeconomic policy since negative macroeconomic drivers such as rising inflation can constrain economic growth. Openness to trade is also deemed to play a crucial role, where reduction and elimination of barriers to trade promote growth in trade and ultimately economic growth.

Keywords: trade variables, cointegration, economic growth

\section{Introduction and Background}

From Adam Smith's discussion of specialisation to the debates about import substitution versus export led growth, economists who investigated determinants of standards of living have also been interested in the effects of trade on economic growth and development (Aradhyula, Rahman and Seenivasan, 2007). Chen (2009) posits that the relationship between trade and economic growth has occupied the development debate for a protracted period. However despite the effort, there is little evidence to link the effects of trade on income growth. The vigour and growing interest in development economics debates related to the relationship between trade and growth reflect the importance and elusiveness placed upon settling the contentious issues both from a theoretical perspective and an empirical perspective. Contentions surrounding these debates relate to whether trade and trade policies play a causal role or they act as a facilitator of other underlying factors affecting growth (Chen, 2009). These contentions are a result of the fact that the ceteris paribus effect of trade on economic growth is difficult to estimate since examining the correlation between the two cannot identify the direction of causality (Ghartey, 1993; Shan and Sun, 1998). Trade may affect incomes through specialisation because of a comparative advantage, exploitation of returns from economies of scale, information exchange arising from improved communication channels and travel and technological spillovers through investments and exposure to new goods and services, new methods of productions and new ways of organisation.

Although theoretically the connection between trade and growth has been established in economic literature (Lee \& Huang, 2012; Chatterji, Mohan \& Dastidar, 2013; Steiner, Wörz, \& Slacík, 2014), empirically, the association between them has proven difficult to establish. This paper, hence seeks to establish the long run empirical relationship between 
trade and economic growth in Zimbabwe using the cointegration technique. Establishing a long run relationship is very important because it allows for deviations in the short run when adjustment mechanisms for variables to their equilibrium values takes place. However in the long run all variables are in equilibrium and so policy considerations are formulated based on equilibrium value of variables.

\section{International Trade and Growth: A theoretical Analysis}

There has been growing theoretical evidence of positive relationships between trade and growth in many developed nations, such relationships has not been proven empirically in developing nations, particularly among African countries. In their attempts to establish such relationships, Edwards (1993) provides a comprehensive review of the key issues on the link between trade and growth in developing countries, particularly the continuing difficulties in obtaining reliable measures of trade policy and identifying precisely the channels through which outward orientation facilitates growth. Furthermore, the African Development Report (2012) identified trade as a powerful tool through which gains from globalisation are distributed within and between nations. However the relationship between trade and growth does not however establish a cause and effect, because as economies grow, they trade more and become more open (Chatterji, Mohan \& Dastidar, 2013). Relaxing foreign exchange controls may increase investment opportunities. These increases in investment bring about new technologies that could increase a country's economic growth. Such investment opportunities can be facilitated through creating trading opportunities and an environment that can attract multinational companies. However benefits from trade depend on the production, nature and characteristics of the goods that a country produces and trades; the domestic economic policies pursued and the trading regime adopted. The static and dynamic gains from trade arise from comparative advantage theory and the effects of trade on the level of investment, and on the state of technical knowledge (Marrewijk, 2012).

Romer, Lucas and Svensson as cited in Chen (2013) argued that international trade can promote economic growth through technology spill over and external stimulation. Similarly, Grossman and Helpman (1990) used endogenous growth models of trade which demonstrate the importance of technological progress and knowledge accumulation. The model generates an endogenous rate of long-run growth that relates trade and growth by means of diffusing technology and knowledge. Rodriguez and Rodrik (1999) relate trade to investment and the resulting growth. Taylor (1993) presented a stylised structuralist model relating trade policy and economic growth, popularly referred to as the two-gap model which explains the poor growth of developing countries. Jayme (2001), using data for Brazil from 1955-1988, could not establish a relationship between trade and growth. However, Frankel and Romer (1999) found that for the Asia and Pacific Economic Cooperation (APEC) countries, productivity per capita increased by between $2 \%$ and $3 \%$ per every percentage increase in the ratio of trade to Gross Domestic Product (GDP), thus confirming an interdependency between trade and economic growth. In a parallel study, Renelt and Levine (1992) and Levine and Zervos (1993) also found a robust two chain link between trade and growth for Central and Southern African countries. Their study revealed a positive robust correlation between economic growth and the share of investment in GDP. A positive and robust correlation between the investment share and the ratio of trade to GDP is also evident in their study. Ndulu and Njuguna (1998) estimated a growth model using GDP as the dependent variable and trade and trade policy variables as explanatory variables. Their results showed that trade matters to economic growth, but macroeconomic variables like the real exchange rate have a strong influence on economic growth as they indirectly affect imports and exports. They also found out that investment affects economic growth directly, but investment is also affected by trade policies. Their results also showed that trade openness through trade liberalisation, is crucial to realise positive relationship between trade and growth in Southern Africa. Asam, Fosu and Ndung'u (2002) however conclude that the proportions of exports and the quality of output affect the strength and quality of growth.

Exports are an important source of income and an engine of growth, so a successful export drive stimulates a positive multiplier effect on the economy with important feedback effects. Ajmia, Ayeb, Balcilarc and Guptad (2013) testing for causality between exports and economic growth in South Africa using linear and non-linear tests, found a cointegrating relationship between the two, and unidirectional causality from GDP to exports. They concluded that exports can improve growth in GDP through increasing employment and incomes in the export sector as well as technological development. Lee and Huang (2002) cite export growth as a key factor in promoting economic growth.

Imports are also intricately linked to economic growth even though there are two competing effects on the demand and supply side. On the demand side, imports are seen as a leakage and constrain economic growth, but the import constraints are eased with trade liberalisation coupled with efficiency gains on the supply side. Mishra (2012) claims that empirical evidence on the nexus between imports and economic growth is rather mixed and inconclusive. If increased GDP is always the source of finance for imports then they can constrain growth and can have a negative impact on 
economic growth. An increase in imports also causes the import substituting domestic market to shrink, therefore reducing investment and ultimately productivity (Lim and Park, 2007).

Another important consideration in this paper is trade openness. Yanikkaya (2002) revealed that there is a positive and significant association between trade openness and growth. As a country opens up its economy (imports plus exports as a ratio of GDP) and participates more in international trade, it becomes integrated into the world economy and can enjoy the static and dynamic benefits accumulating from international trade. According to Yanikkaya (2002), the most basic measure of openness is the simple trade shares, which is exports plus imports divided by GDP and studies have found a positive and strong relationship with growth. For example, Gries and Redlin (2012) using the trade measure, imports and exports as a ratio of GDP as an openness measure, found a significant relationship between GDP growth and openness. The same measurement is also the one used to measure trade openness in the Penn World Tables.

An increase in the capital stock available for an economy results in the economy attaining a high growth path in the future through capital accumulation and increase in production capacity of the economy. Anwer and Sampath (1999) using a cointegration approach, found investment to have a short and long run positive relationship with GDP growth for 90 countries for the period 1962-1992. The current research also considers investment as an explanatory variable in the analysis with other macroeconomic variables. Chude and Chude (2013) claim that government expenditure has an important role to play in the determination of economic growth for developing countries. This derives from the Keynesian view where government expenditure is used as an instrument to stimulate aggregate demand and hence promote economic growth. However, an unsustainably high level of government expenditure may exceed the fiscal revenue leading to a budget deficit. Checherita and Rother (2010) argue that a high level of government budget deficit, and ultimately public debt has negative growth effects on the economy.

A stable macroeconomic environment signified by low and stable inflation plays an important role in determining growth of an economy and promotion of international trade. Gokal and Hanif (2004) argued that inflation imposes negative externalities on the economy as it affects an economy's efficiency, leads to uncertainty and affects future profitability of investment projects. Furthermore an economy's international competitiveness is also negatively affected by high inflation by reducing purchasing power of a currency, making exports relatively expensive and leading to deficits in the balance of payment. Corden (1985) analysed foreign trade together with macro-economic variables and especially emphasized the impact of trade on the supply of production factors and productivity. A country's foreign trade is always linked to its macroeconomic policies. According to Corden (1985), there are five (5) main aspects in relation to foreign trade that could affect a country's economy and these are the revenue effect, the effect of capital accumulation, the substitution effect, the income distribution effect and the effect of the weighted elements. These effects are cumulative, which means that the impact of trade on economic growth is strengthened gradually as the development of the economy progresses. According to Chen, (2009) taking foreign trade and other factors as independent variables to explore the relationship quantitatively between the two cannot only explain the relationship accurately, but also make the affecting extent of independent variables on dependent variables clear.

\section{Methodology}

In trying to establish the long run relationship between international trade and economic growth, the study employed the Engle-Granger cointegration technique, using the Ordinary Least Squares (OLS) procedure to estimate a growth equation with GDP as the dependent variable. Parameter estimates generated by this technique possesses all desirable properties (best linear, and unbiased estimator), and the error term in the model estimated using the OLS procedure captures the effects of other factors not specified. A cointegration and error correction modelling was employed to establish the short run dynamics and the speed of adjustment to the long run equilibrium. The methodology follows the growth regression literature inspired by Barro (1991) and the literature review provided the diverse explanatory variables that were included in the model depending on the aim and objective of the studyThe current study makes use of the variables that were identified by Ndulu and Njuguna (1998), Rodriguez and Rodrik (1999), Renelt and Levine (1992) and Levine and Zervos (1993) to undertake a cointegration analysis in order to establish a link between trade and economic growth.. Explanatory variables include export share of GDP (EXGDP), import share of GDP (MGDP), trade openness (OPEN) (imports plus exports as a ratio of GDP), inflation (INFL), investment (INV), government expenditure (GVT) and government budget deficit as a share of GDP (DEF). Stationarity tests of the variables was done using the Augmented Dickey Fuller (ADF) procedures, with non-stationary variables being made stationary by first differencing.

Testing for cointegration between two or more non-stationary time series using the Engle Granger approach, involves running an OLS regression, saving the residuals and then running the ADF test on the residual to determine if it is stationary. The variables are said to be cointegrated if the residual is stationary. According to the Engle- Granger 
theorem if two variables $y$ and $x$ are cointegrated, then the relationship between the two can be expressed as an error correction model $(E C M)$, in which the error term from the non-stationary regression model, lagged once, acts as the error correction term. In this case the cointegration provides evidence of a long-run relationship between the variables, whilst the ECM provides evidence of the short-run relationship. This test has the advantage that it is intuitive, easy to perform and master (Bo Sjo", 2008).

The study utilises annual time series data for Zimbabwe for the period 1975-2005. It is important to note that due to the economic meltdown in Zimbabwe it was difficult, if not impossible to obtain reliable and credible data for the Zimbabwean economy from 2006 to 2009. Therefore this limited the study to 30 observation points used in the time series analysis. However Mikesell and Zinser (1973) posit that it is almost impossible to obtain accurate data in any developing country, hence the data this study is not free from this apparently common data problem. Nonetheless, this does not annul the findings of the study.

\section{Findings and Discussion}

The real values of variables, were converted to logs, tested for stationarity using the ADF test, and found to be nonstationary in levels at $5 \%$ level of significance (Table 1). All variables were then differenced once and all except GVT and DEF, were found to be stationary at $5 \%$ level of significance, thus integrated of order one, I (1), making it possible to conduct cointegration tests on the variables (Table 2).

Table 1. Augmented Dickey Fuller (ADF) Test Results in Levels

\begin{tabular}{lccc}
\hline \multicolumn{1}{c}{ Variable } & t- ADF Statistic & Critical 5\% & conclusion \\
\hline LGDP & -0.18829 & -2.9665 & Non-stationary \\
LINFL & -0.42314 & -2.9665 & Non-stationary \\
LEXGDP & -0.21756 & -2.9665 & Non-stationary \\
LMGDP & -0.98750 & -2.9665 & Non-stationary \\
LGVT & -0.85479 & -2.9665 & Non-stationary \\
LOPEN & -2.31058 & -2.9665 & Non-stationary \\
LDEF & -1.87546 & -2.9665 & Non-stationary \\
LINVEST & -0.68547 & -2.9665 & Non-stationary \\
\hline
\end{tabular}

Table 2. Augmented Dickey Fuller (ADF) Test Results after $1^{\text {st }}$ Differencing

\begin{tabular}{lccc}
\hline \multicolumn{1}{c}{ Variable } & t- ADF Statistic & Critical 5\% & conclusion \\
\hline$\Delta$ LGDP & -5.02465 & -3.5731 & stationary \\
$\Delta$ LINFL & -3.62187 & -3.5731 & stationary \\
$\Delta$ LEXGDP & -4.68548 & -3.5731 & stationary \\
$\Delta$ LMGDP & -4.67014 & -3.5731 & stationary \\
$\Delta$ LGVT & -2.85395 & -3.5731 & non-stationary \\
$\Delta$ LOPEN & -3.85784 & -3.5731 & stationary \\
$\Delta$ LDEF & -3.48659 & -3.5731 & non-stationary \\
$\Delta$ LINVEST & -5.87695 & -3.5731 & stationary \\
\hline
\end{tabular}

To test for cointegration, the Engle-Granger procedure was used with an OLS regression run on the non-stationary series incorporating all variables found to be integrated of order 1, residuals were saved and an ADF test was performed on the residuals which were found to be stationary. The equation run was in natural logs and in the form:

$L G D P=\alpha+\beta_{0}+\beta_{1} L I N F L+\beta_{2} L E X G D P+\beta_{3} L M G D P+\beta_{4} L O P E N+\beta_{5} L I N V E S T+\varepsilon_{t}$

The results for the non-stationary series are given below: 
Table 3. Initial regression results

\begin{tabular}{lllll}
\hline variable & coefficient & Standard error & t-statistic & p-value \\
\hline Constant & $-526,7010$ & 241.1584 & -2.1840 & 0.0495 \\
LINFL & -1.4999 & 1.0729 & -1.3980 & 0.1874 \\
LEXGDP & 2.4549 & 8.3722 & 2.2121 & 0.0471 \\
LMGDP & -1.3475 & 1.1507 & -2.2267 & 0.0459 \\
LOPEN & 3.3617 & 8.7573 & 2.2175 & 0.0466 \\
LINVEST & 2.8269 & 2.4968 & 1.1322 & 0.2797 \\
\hline
\end{tabular}

L denotes Natural Logs operator.

R- Squared $=0.40 \quad$ F-statistic $=1.02 \quad$ DW statistic $=3.42 \quad$ Prob (F-statistic $)=0.47$

However it is important to note that standard errors, and hence the t-statistics of the coefficients from the results of the equation in natural logs are not useful since they follow an unknown distribution because the variables therein are nonstationary. No logical inference can and should thus be drawn from such results.

The results from the cointegration test are given are shown in table 4.

Table 4. Unit Root test for residuals/cointegration test

\begin{tabular}{cc}
\hline t-ADF Statistic & Critical values \\
\hline-3.043215 & $2.97055 \%$ \\
& $-2.624210 \%$ \\
\hline
\end{tabular}

The table indicates that the residuals are stationary at both $5 \%$ and $10 \%$ level of significance since the ADF t-statistic is greater than the critical values. This confirms the existence of a long run relationship (cointegration) between the dependent and independent variables in the model which are integrated of the same order I (1). This necessitate the formulation of an Error Correction Model (ECM) to account for the variable relationships both in the short and long run and to determine speed of adjustment to long run equilibrium values of the variables. Formulating the ECM involve regressing the first differences of the dependent variable $(\Delta L G D P)$ onto the first differences of the explanatory variables plus the lagged value of the error correction term $\left(\mathrm{ECM}_{\mathrm{t}-1}=\right.$ error correction term lagged once) from the cointegrating equation. The ECM equation is given as:

$\triangle L G D P=\beta_{0}+\beta_{1} \Delta L I N F L+\beta_{2} \Delta L E X G D P+\beta_{3} \Delta L M G D P+\beta_{4} \Delta L O P E N+\beta_{5} \Delta L I N V E S T+E C M_{t-1}+\varepsilon_{t}$

Table 5. ECM results

\begin{tabular}{lcccc}
\hline \multicolumn{1}{c}{ variable } & coefficient & Standard error & t-statistic & $\mathrm{p}$-value \\
\hline Constant & 0.3177 & 0.2241 & 1.4176 & 0.1840 \\
$\Delta$ LINFL & -1.5126 & 0.5336 & -2.8343 & $0.0162^{\star *}$ \\
$\Delta$ LEXGDP & 7.7767 & 8.8145 & 7.4433 & $0.0000^{\star *}$ \\
$\Delta$ LMGDP & -478.1573 & 63.3595 & -7.5467 & $0.0000^{\star *}$ \\
$\Delta$ LOPEN & 1.2338 & 1.6334 & 7.4916 & $0.0000^{* *}$ \\
$\Delta$ LINVEST & 2.4194 & 1.0518 & 2.3002 & 0.1420 \\
ECMt-1 & -1.7817 & 0.1685 & -10.5761 & $0.0000^{\star *}$ \\
\hline
\end{tabular}

$\Delta$ denotes the first difference operator ${ }^{\star \star}$ denotes significance at $5 \%$ level of significance

$\mathrm{R}^{2}=0.95 \quad$ DW statistic $=1.57 \quad$ F-statistic $=26.76(0.0000)$

Diagnostic tests were carried out on the model and the residuals were found to be normally distributed, thus confirming the model to be internally consistent. The Ramsey Reset test indicated a $P$ value of 0.75 , thus rejecting the presence of specification errors in the model. The ARCH LM test $P$ value of 0.67 indicated that there is no autocorrelation in the model.

The explanatory variables in the ECM are significant except investment and the constant. The insignificance of investment can be explained by interest rate controls that prevailed in the Zimbabwean economy for a long time since 1980s. Financial repression (McKinnon, 1973 and Shaw, 1973) can lead to very low investments as the source of funds is repressed. The results indicate a strong and positive relationship between GDP and exports as shown by the significance of the export variable. The results reinforce the results of the study by Lee and Huang (2002), wherein exports are found to be the key to economic growth. Overreliance of the country on imports and their leakage effect has negative growth 
effects, as shown by the negative sign of the import coefficient. However, overall trade variables are significant in explaining output growth in the economy. As the country becomes more open and participates more in international trade, its income also increases. Other macroeconomic variables, like inflation and government budget deficit, are significant and have negative effects on economic growth. In a highly inflationary environment, purchasing power is eroded, thus reducing aggregate demand and also increasing production costs on the supply side, and negatively impacting on economic growth. This corroborates with findings of other scholars who also recognised the importance of the macroeconomic variables to economic growth (Chude and Chude, 2013; Checherita and Rother 2010; Gokal and Hanif, 2004; and Fargo, 1999).

The results also demonstrated that trade variables work in conjunction with non-trade variables such as inflation which can erode the competitiveness of the external sector. Deteriorating macroeconomic conditions inhibited export growth through high inflation and nominal interest rates. A stable macroeconomic environment signified by low inflation encourages growth in trade thereby contributing to positive economic growth. The influence of trade enhancing policies operate more effectively in a more open trade environment which permits enterprises to take advantage of international opportunities to trade and investment. The results indicate that export performance contributes to output growth as shown by the significance of the export and openness variables (DEXGDP, DOPEN). This suggest that trade policies aimed at restoring international competitiveness to expand and diversify exports have the potential of promoting and sustaining growth of GDP for the Zimbabwean economy in the long term.

\section{Conclusion}

The study aimed at establishing if there exists a cointegrating relationship between GDP as the endogenous variable, and trade variables and macroeconomic variables as exogenous variables. The results indicated that cointegration exists showing that there is a long run relationship between GDP and its regressors. The results also demonstrated that a stable macroeconomic environment is also necessary to encourage growth in trade and ultimately economic growth. the influence of trade enhancing policies operate more effectively in a more open trade environment which permits enterprises to take advantage of international opportunities to trade and investment. This suggest that trade policies aimed at restoring international competitiveness for expansion and diversification of exports have the potential of promoting and sustaining economic growth for the Zimbabwean economy in the medium to long term.

\section{References}

Ajmi, A.N., Ayeb, G.C., Balcilarc, M. \& Guptad, R. (2013). Causality between Exports and Economic Growth in South Africa: Evidence from Linear and Nonlinear Tests. Working Paper Series University of Pretoria Department of Economics

Anwer, M.S., \& Sampath, R.K. (1999). Investment and Economic Growth. Presented at Western Agricultural Economics Association Annual Meeting, July 11-14, 1999, Fargo, ND.

Aradhyula, S., Rahman, T., \& Seenivasan, A. (2007). Impact of International Trade on Income and Income Inequality. Paper presented at American Agricultural Economics Association Annual Meeting, Portland July 29-August 1, 2007.

Asam, J., Fosu, A., \& Ndung'u, N.S. (2002). Explaining Slow Growth in Africa. African Development Review 14(2): 177-220.

Barro, R.J. (1991). Economic Growth in a Cross Section of Countries. The Quarterly Journal of Economics, Vol. 106, No. 2. p. 407-443.

Bo Sjo". (2008). Testing for Unit Roots and Cointegration. www.iei.liu.se/nek/ekonometrisk-teori-7-5-hp.../dfdistab7b.pdf. Accessed 10 April 2014

Chatterji, M., Mohan, S., \& Dastidar, S.G. (2013). Relationship between trade openness and economic growth of India: A time series analysis. SIRE Discussion Papers, Scottish Institute for Research in Economics (SIRE).

Checherita, C., \& Rother, P. (2010). The Impact of High and Growing Government Debt on Economic Growth an Empirical Investigation for the Euro Area. ECB Working Paper Series

Chen, H. (2009). A Literature Review on the Relationship between Foreign Trade and Economic Growth. International Journal of Economics and Finance, Vol 1, Number 1.127-131

Chude, N.P., \& Chude, D.I. (2013). Impact of Government Expenditure on Economic Growth in Nigeria. International Journal of Business and Management Review. Vol.1, No.4, 64-71.

Corden, M.W. (1985). Protection, growth and trade: Essays in international economics, Basil Blackwell, Oxford Publishers

Curwin, K.D., \& Mahutga, M.C. (2014). Foreign Direct Investment and Economic Growth: New Evidence from Post-Socialist Transition Countries. Oxford Journal of Social Forces Vol 92 Issue 3. 1159-1187

Edwards, S. (1993). Openness, Trade Liberalization, and Growth in Developing Countries Journal of Economic Literature, Vol XXXI, 1358-1393.

Frankel, J.A., \& Romer, D. (1999). Trade and Growth: An Empirical Investigation NBER Working Papers

Ghartey, E.E. (1993). Causal Relationship between Exports and Economic Growth: Some Empirical Evidence in Taiwan, Japan and the US. Applied-Economics. (9): 1145-1152. 
Gokal, V., \& Hanif, S. (2004). Relationship between Inflation and Economic Growth. Working Paper 2004/04, Reserve Bank of Fiji.

Gries, T., \& Redlin, M. (2012). Trade Openness and Economic Growth: A Panel Causality Analysis. Source: http://faculty.washington.edu/karyiu/confer/sea12/papers/SG12-112\%20Redlin.pdf Accessed 10 April 2014

Grossman, G.M., \& Helpman, E. (1990). Trade, Innovation, and Growth. American Economic Review Volume 80 (2), 86-91.

Jayme, F.G. Jr. (2001). Notes on Trade and Growth. Textos para Discussão Cedeplar-UFMG td166.

Lee, C., \& Huang, D. (2012). Human Capital Distribution, Growth and Trade. Bulletin of Economic Research and John Wiley \& Sons Ltd Volume 66, Issue 1.1467-8586

Levine, R., \& Renelt, D. (1992). A Sensitivity Analysis of Cross-Country Growth Regressions. The American Economic Review, Vol. 82 , No. 4. p. $942-963$.

Levine, R., \& Zervos, S.J. (1993). What We Have Learned About Policy and Growth from Cross-Country Regressions. AEA Papers and Proceedings 83: 426-430.

Lim, H., \& Park, S. (2007). Could Imports be Beneficial for Economic Growth: Some Evidence from Republic of Korea, ERD Working Paper Series No. 103 Asian Development Bank.

Marrewijk, C. (2012). International Economics: Theory, Application and Policy. Oxford University Press, Oxford.

Matthew, O.H., \& Johnson, A. (2014). An Investigation of the Impact of Foreign Direct Investment on Economic Growth in Nigeria: A Rigorous Approach. Journal of Poverty, Investment and Development. Vol 3. 33-41.

Mikesell, R.F., \& Zinser, J.E. (1973). The nature of the saving function in developing countries: a survey of the theoretical and empirical literature. Journal of Economic Literature, Vol.11, No.1, 1-26.

Mishra, P.K. (2012). The Dynamics of the Relationship between Imports and Economic Growth in India. South Asian Journal of Macroeconomics and Public Finance Vol. 1, Issue 1, 57-79

Ndulu, B.J., \& Njuguna, N.S. (1998). Trade policy and regional integration in Sub-Saharan Africa.: Paper presented at the IMF, African Economic Research Consortium Seminar on Trade Reform and Regional Integration in Africa, December 1- 3, 1997. Washington, D.C: IMF Inst., Internat. Monetary Fund, No 1237: 239-277

Rodriguez, F., \& Rodrik, D. (1999). Trade Policy and Economic Growth: A Skeptic's Guide to Cross-National Evidence. NBER Working Paper No. 7081.

Shan, J., \& Sun, F. (1998). On The Export-led Growth Hypothesis: The Econometric Evidence From China. International Journal of Economics and Finance Vol. 1, No. 1. 341-351.

Steiner, K., Wörz, J., \& Slacík, T. (2014). Can Trade Partners Help Better FORCEE the Future? Impact of Trade Linkages on Economic Growth Forecasts in Selected CESEE Countries. Focus on European Economic Integration, Vol. 1: $36-56$

Taylor, L. (ed.), (1993). The Rocky Road to Reform: Adjustment, Income Distribution, and Growth in the Developing World, Cambridge: MIT Press.

UNDP, (2012). African Development Report.

Yanikkaya, H. (2003). Trade Openness and Economic Growth: A Cross-Country Empirical Investigation. Journal of Development Economics 72, 57- 89 